\title{
Folding Style Analysis of the Tabnak Sweet Gas Field, Zagros, Iran
}

\author{
Marzieh Badrkhani, Zahra Maleki*, Mehran Arian \\ Department of Geology, Science and Research Branch, Islamic Azad University, Tehran, Iran \\ Email: ${ }^{2}$ z.maleki@srbiau.ac.ir
}

Received 21 January 2016; accepted 27 August 2016; published 30 August 2016

Copyright (C) 2016 by authors and Scientific Research Publishing Inc.

This work is licensed under the Creative Commons Attribution International License (CC BY). http://creativecommons.org/licenses/by/4.0/

(c) $\underset{\mathrm{EY}}{\mathrm{i}}$ Open Access

\section{Abstract}

The Zagros fold-thrust belt in Iran is home to one of the enormous petroleum producing reservoirs in the word. The Tabnak gas field in this belt is one of the enormous sweet gas fields that discovered on the land. This anticlinal structure is located in the Coastal Fars sub-basin and is bounded from North by the Varavi gas field, from South by the Kuh-e Madar anticline, from East by Assaluyeh gas field and from West by Kuh-e Dehnow anticline. Its length is about $80 \mathrm{~km}$ and width is about $15 \mathrm{~km}$. This structure is asymmetric anticline and is located with irregular near the Assaluyeh gas field. The Tabnak gas field is deepest structure between anticlines in the Coastal Fars area. This gas field has a special place for accommodating the enormous Hydrocarbon resources and for this reason, it is very important for Iran country. In this structure, the Dashtak, Kangan and upper Dalan Formations have Hydrocarbon. Analysis and description of fold style elements are essential for structural studies. Based on this case, the comparison of the fold styles and folding mechanism is possible. The main aim in this research is the analysis of the fold style elements of the Tabnak anticline for determining the folding pattern and tectonic regime on this structure. This case has very important for Hydrocarbon exploration between gas fields in the Fars area. In this research, we used the Tectonics FP software, Global Mapper software and geological maps and reports of Iranian National Oil Company. In addition, we used common classification of fold for indicating folding mechanism of the Tabnak anticlinal structure. Based on analysis of the fold style elements, the Tabnak anticlinal structure has variation in fold style. This structure has three different fold styles in different parts. The changes of fold axis, axial plane characteristics and fold classification confirmed several fold styles in different parts of the Tabnak anticline. These changes are observed specially in B-B', F-F' and G-G' sections of this anticline. It seems that these parts have been suffered more deformation in the study anticline. In addition, based on interlimb and folding angle, fold type is close type in all of parts. The close type required more accuracy, because the close type may be ensigns of complication regime. In the study area, G-G' and F-F' section of the Tabnak gas field probable show folding style changes have been affected by Gavbandy Paleo-high.

${ }^{*}$ Corresponding author. 


\section{Keywords}

\section{Tabnak Anticline, Costal Fars, Folding Style, Gavbandi Paleo-High}

\section{Introduction}

The Zagros fold-thrust belt is home to one of the largest petroleum producing reservoirs in the word [1]. Prolific gas fields have been found in the Fars area of the Zagros belt and on the Gavbendi Paleo-High or Qatar Arch in offshore or onshore. The offshore gas Prolific fields are North Dome-South Pars, North Pars and Balal and as well as in onshore Kangan, Nar, Aghar, Dalan, Varavi, Assaluyeh, Gardan, Tabnak, Homa, Lavan and Kish [2]. One of the main onshore gas fields the Tabnak gas field is located in the Coastal Fars sub-basin of this belt and East of the Assaluyeh gas field anticlinal structure. This field is considered as one of the biggest sweet gas fields on land and is limited to from north by the Varavi gas field, from East by the Kuh-e Dehnow anticline, and from south by the Madar anticline. The length of this anticline is on the ground about $80 \mathrm{~km}$ and the width is nearly $15 \mathrm{~km}$.

The sedimentary cover in the Zagros belt has 12,000 meters thick and various stratigraphic characteristics. This sedimentary cover has been accumulated enormous oil and gas reserves. In stratigraphic units of the Zagros, the Permo-Triassic carbonate has very important value in the Fars province of the Zagros belt. These stratigraphic units have high gas reserves extra than 900 TCF [3]-[6], especially in the Dalan and Kangan formations in southwestern of Iran (Figure 1). The Permo-Triassic carbonates have been reviewed and investigated by many researchers such as Kashfi (1992) [7], Alsharhan and Narin (1994) [5] focused on petroleum geology, stratigraphy and characteristics of sedimentary environment.In the Costal Fars of the Zagros fold-thrust belt, National Iranian Oil Company has discovered nearly thirty prolific supergiant gas fields. Some prolific supergiant gas fields have been discovered on the Qatar Arch (Hamoon and South Pars), and some of these gas fields have been discovered on the Gavbandi paleo-high or Coastal Fars area (such as Kangan, Tabnak, Varavi, Homa, Shanul and Assaluyeh) (Table 1). Based on Bordenave and Hegre (2010) [8], in most of these gas fields of the Zagros belt, the enormous gas reserves accumulated either in the Upper Dalan and Kangan reservoiror in the Dalan, Kangan and Lower Dalan reservoirs. The most of Dalan-Kangan carbonate reservoirs in the Zagros belt have been discovered in the Costal Fars area (Table 1). The Traps types in these gas fields in the Zagros area are salt Dome trap and Anticline trap. All of the supergiant gas fields in the Costal Fars are Anticline trap, such as Assaluyeh, Tabnak, Kuh-e Mand and Dalan gas field (Table 1).

The Tabnak anticline is located as disharmonic form to the Assaluyeh anticlinal gas field and is an asymmetric anticlinal structure. This structure is considered as deepest as buildings among the "sets of the Assaluyeh
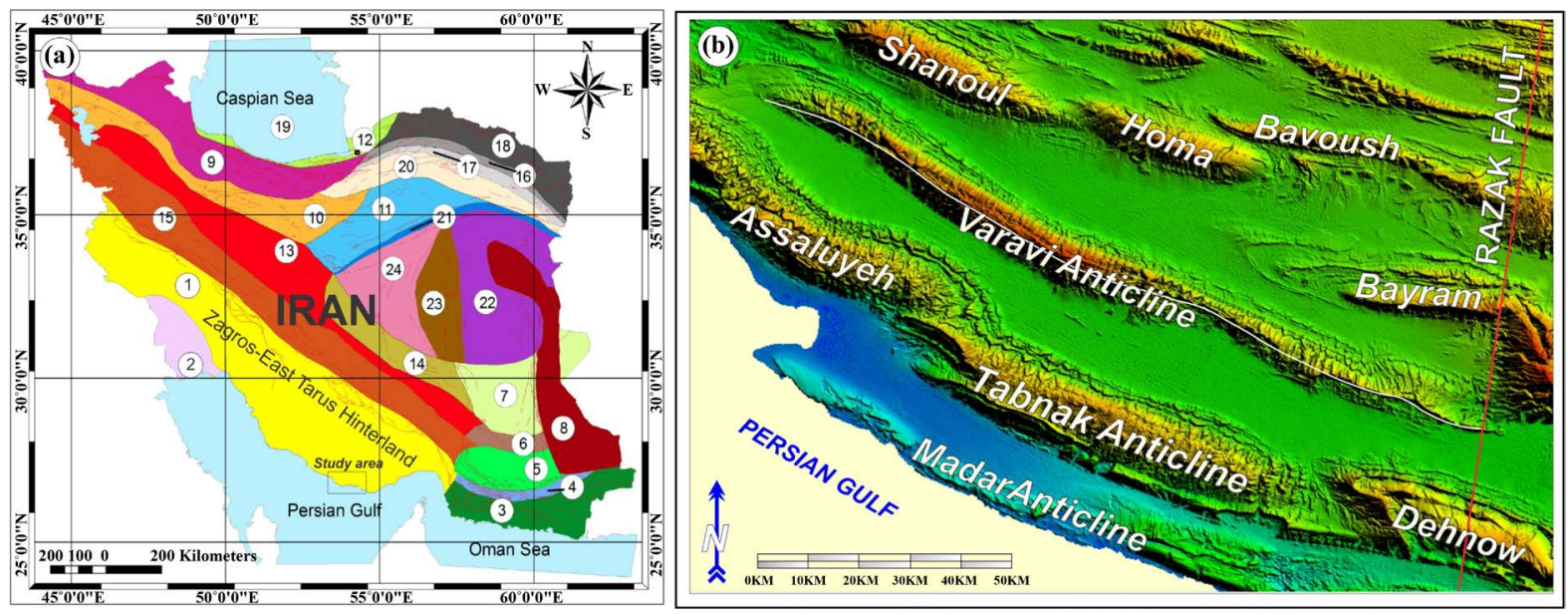

Figure 1. (a) This map shows location of the study area (black rectangular) in the Physiographic-tectonic zoning map of Iran's sedimentary basin [9]. (b) SRTM image of the study area shows the Tabnak Anticline and their adjacent anticlines in the Coastal Fars sub-basin. 
Table 1. The main oil- and gas-fields producing in the Coastal Fars area (Zagros fold-thrust belt) from Dalan-Kangan carbonate reservoirs (SW Iran) (based on [3]).

\begin{tabular}{ccccccc}
\hline NO & Field & Year of discovery & Geologic setting & Trap type & Field size $\mathbf{( k m )}$ & Reservoir unit \\
\hline 1 & Kuh-e-Mond & 1976 & Coastal Fars & Anticline & $5 \times 1$ & U-Dalan, Kangan \\
2 & Kangan & 1978 & Coastal Fars & Anticline & $5 \times 0.8$ & U-Dalan, Kangan \\
3 & W-Assaluyeh & 2006 & Coastal Fars & Anticline & $2.8 \times 0.8$ & U-Dalan, Kangan \\
4 & E-Assaluyeh & 2008 & Coastal Fars & Anticline & $2.9 \times 0.8$ & Dalan, Kangan \\
5 & Tabnak & 1999 & Coastal Fars & Anticline & $6 \times 1.2$ & U-Dalan, Kangan \\
6 & Zireh & 2000 & Coastal Fars & Anticline & $0.5 \times 3.5$ & U-Dalan, Kangan \\
7 & Nar & 1974 & Coastal Fars & Anticline & $0.8 \times 3$ & L/U-Dalan, Kangan \\
8 & Varavi & 1975 & Coastal Fars & Anticline & $0.5 \times 5$ & U-Dalan, Kangan \\
9 & Gardan & 1991 & Coastal Fars & Salt Dome & $1.5 \times 1.2$ & U-Dalan, Kangan \\
10 & Sefid Baghun & 2008 & Coastal Fars & Anticline & $0.8 \times 3.5$ & U-Dalan, Kangan \\
11 & Homa & 2000 & Coastal Fars & Anticline & $0.8 \times 3.5$ & U-Dalan, Kangan \\
12 & Shanul & 1995 & Coastal Fars & Anticline & $0.7 \times 3.5$ & U-Dalan, Kangan \\
13 & Dalan & 1975 & Coastal Fars & Anticline & $1 \times 4$ & L/U-Dalan, Kangan \\
14 & Day & 2000 & Coastal Fars & Anticline & $2.2 \times 0.7$ & Nar, U-Dalan, Kangan \\
15 & Halegan & 2009 & Coastal Fars & Anticline & $2.2 \times 0.7$ & L-Danlan/Nar/U-Dalan, Kangan \\
16 & Sefid Zakhur & 2005 & Coastal Fars & Anticline & $2.5 \times 0.7$ & L-Danlan/Nar/U-Dalan, Kangan \\
\hline
\end{tabular}

anticlines”. The Tabnak Sweet gas field as one of the biggest sweet gas fields on land in order to accommodate the huge hydrocarbon resources has a special place in the Middle East countries. Investigation and analysis of factors affecting are important in the development and geometry anticlinal structures in the foreland of the Zagros fold-thrust belt. This case has special importance in investigating the effects of major faults for study of the oil-rich regions of Zagros hydrocarbon traps. Until now, many researchers have been analyzed the geometric style of folds. Deformation and mechanical performance stratigraphic units have affected the geometry anticlines of the Zagros belt and the Zagros folding style is strongly influenced by the mechanical behavior of rock units.

\section{Material and Methods}

This paper presents part of the results of a regional study of the Coastal Fars area in the Zagros Simply folded belt, based on original fieldwork, satellite images, structural sections, geological maps and well data. We used fold style elements analysis methods (description of folds) based on [10]-[13]. We used Tectonics FP software for prepared and analyzed Stereoplots of the Tabnak anticline. In addition, we used Global Mapper Software for prepared 3D SRTM of the study area and 3D Path Profile (along cross sections) based on Global Mapper Software.

\section{Geological Setting and Stratigraphy}

The Zagros orogenic belt has Northwest-Southeast trend and this belt is located from Anatolian Eastern fault to Oman lineament in South of Iran. This belt as fold-thrust belt is bounded from North boundary by Iran plate and from South boundary by Northeastern edge of Arabian plate. The Convergent continental-continental plates of the Iran and Arabia-Africa in upper cretaceous have formed the Zagros orogenic belt that continuous to present day. This convergent has caused close the Neotethys [14]. The consequent of this convergent, numerous folds and thrust have been created and many researchers studied about this (e.g. [14]-[28]). The Zagros orogenic belt has 200 - $300 \mathrm{~km}$ width and this belt is located along with other parts of the Zagros belt from Anatolian Eastern part toward Oman line in South of Iran.

The main dominant structures in the Zagros fold-thrust belt are folds and thrusts with NorthwesternSoutheastern trend. These structures has main tendency toward Southwestern. Based on morphology view, this belt is divided to High Zagros and Folded Zagros. This belt has average height of near to 1200 meters. Accord- 
ing to structural classification, the Zagros fold-thrust belt from Northeastern to Southeastern is divided to; High Zagros Thrust Belt, Simply Folded Belt, Zagros Foredeep and Coastal Plane [29]-[31]. This belt based on facies changes from Northwestern to Southeastern divided to Lurestan basin (Northwestern of Zagros), Khuzestan basin (Central Zagros) and Fars basin (Southeastern of Zagros). The Fars basin has three parts includes the Interior Fars, External Fars and Bandar Abbas hinterland. The External Fars has subdivided; Costal Fars and Sub-Costal Fars [31]. In the Zagros fold-thrust belt, the Fars geological province, based on geological facies units perpendicular to the Zagros belt has divided into the Interior Fars, Sub-Coastal and Coastal Fars sub-basins [31]. Based on this case, the study area is located in the Coastal Fars sub-basin or Fars Platform (Figure 2, Figure 3). The significant geological characteristics in the Fars area are:

- Based on sedimentary facies and stratigraphic characteristics, the Fars area has platform conditions. This case has caused continuity of Arabian basement from the Qatar to the Fars area. This part has been nominated Gavbandi Paleo-high [31].

- The folded structures (mainly anticlines) have various trends such as Eastern-Western, NorthwesternSoutheastern and some anticlines have Northeastern-Southwestern trend. The structures trends changes have caused base on basement fault activities or rotation of Arabian plate to Iranian plate.

- The folding pattern in the Fars area has followed concentric pattern that main decollement unit is Hormoz series and minor decollements are the Dashtak Formation evaporites, Gurpi and Pabdeh Formation Shales.

In the Fars area, Permo-Triassic units has great significant characteristics base on gas reservoirs [4]-[6]. The gas reserves (>900 TCF) are present in Permo-Triassic carbonates of the Fars area in Dalan and Kangan Formations (Khuff-equivalent) [4]-[6]. Reservoir rock quality in this unit is strongly influenced by tectonic setting and depositional environment, and by diagenesis [3]-[7]. One of the main Gas field as sweet gas field of onshore incoastal Fars is the Tabnak gas field and other Dalan-Kangan carbonate reservoirs have shown in Table 1. The type of Main gas fields in the Coastal Fars of the Zagros belt is anticline traps (Table 1).

Based on Bordenave and Hegre (2014) [2] most of the current gas fields discovered in Fars (Aghar, Assaluyeh, Dalan, Gardan, Homa, Kangan, Mand, Nar, Shanul, Tabnak, and Varavi) and in the Persian Gulf (Balal, Kish, Lavan, North Dome-South Pars, and North Pars) are located near the top of the Gavbendi Pleo-High. The Tabnak gas field has been discovered in 1967. It began production in 1980 and produces natural gas and condensates. The total proven reserves of the Tabnak gas fields are around 30 trillion cubic feet $\left(857 \times 109 \mathrm{~m}^{3}\right)$ and production is slated to be around 1.5 billion cubic feet/day $\left(43 \times 106 \mathrm{~m}^{3}\right)$. The Tabnak gas field is an anticlinal structure, anticline oil trap and the largest field discovered in the land sweet gas.

\section{Folding Mechanism Analysis}

Determination of the fold mechanism is the main part of structural analysis and description of fold geometry is

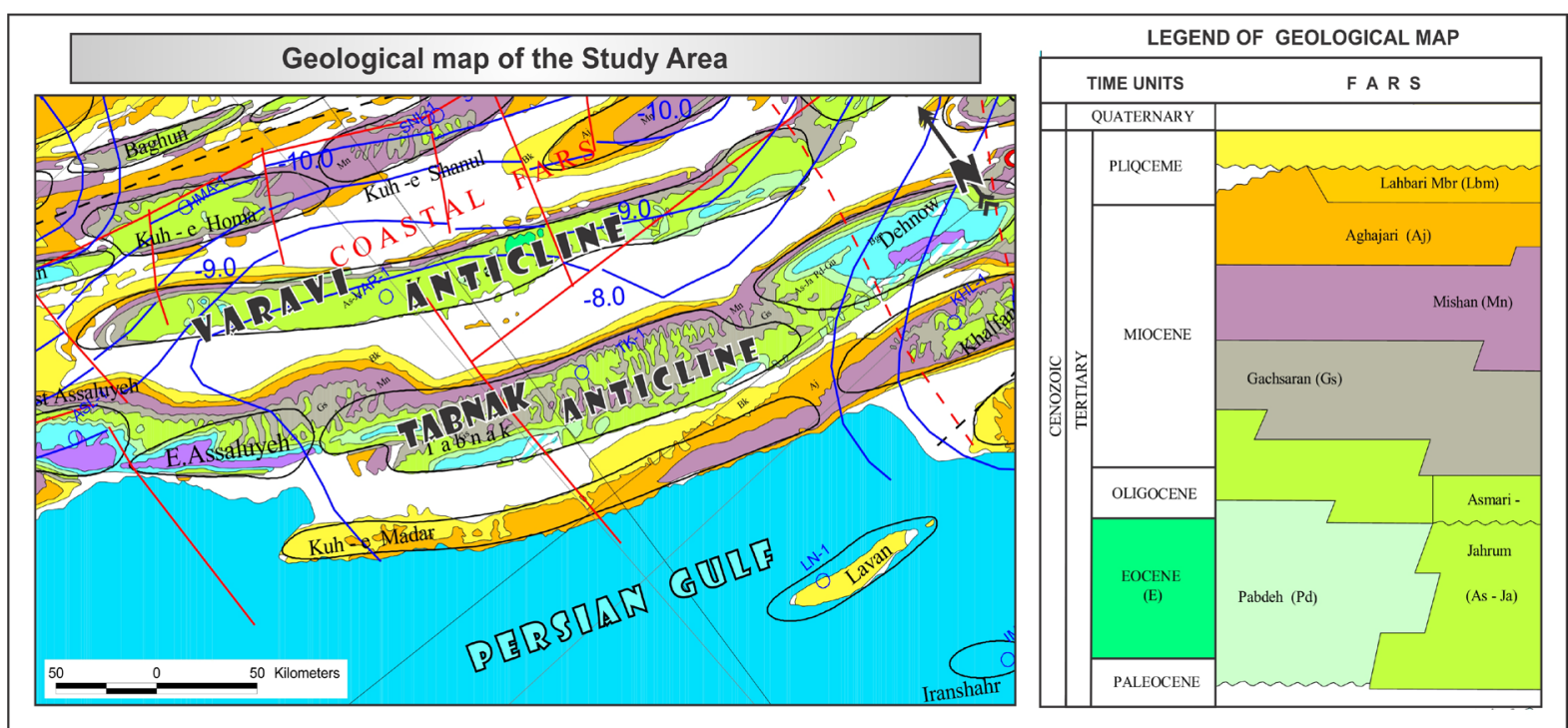

Figure 2. Geological map of the study area [32]. 


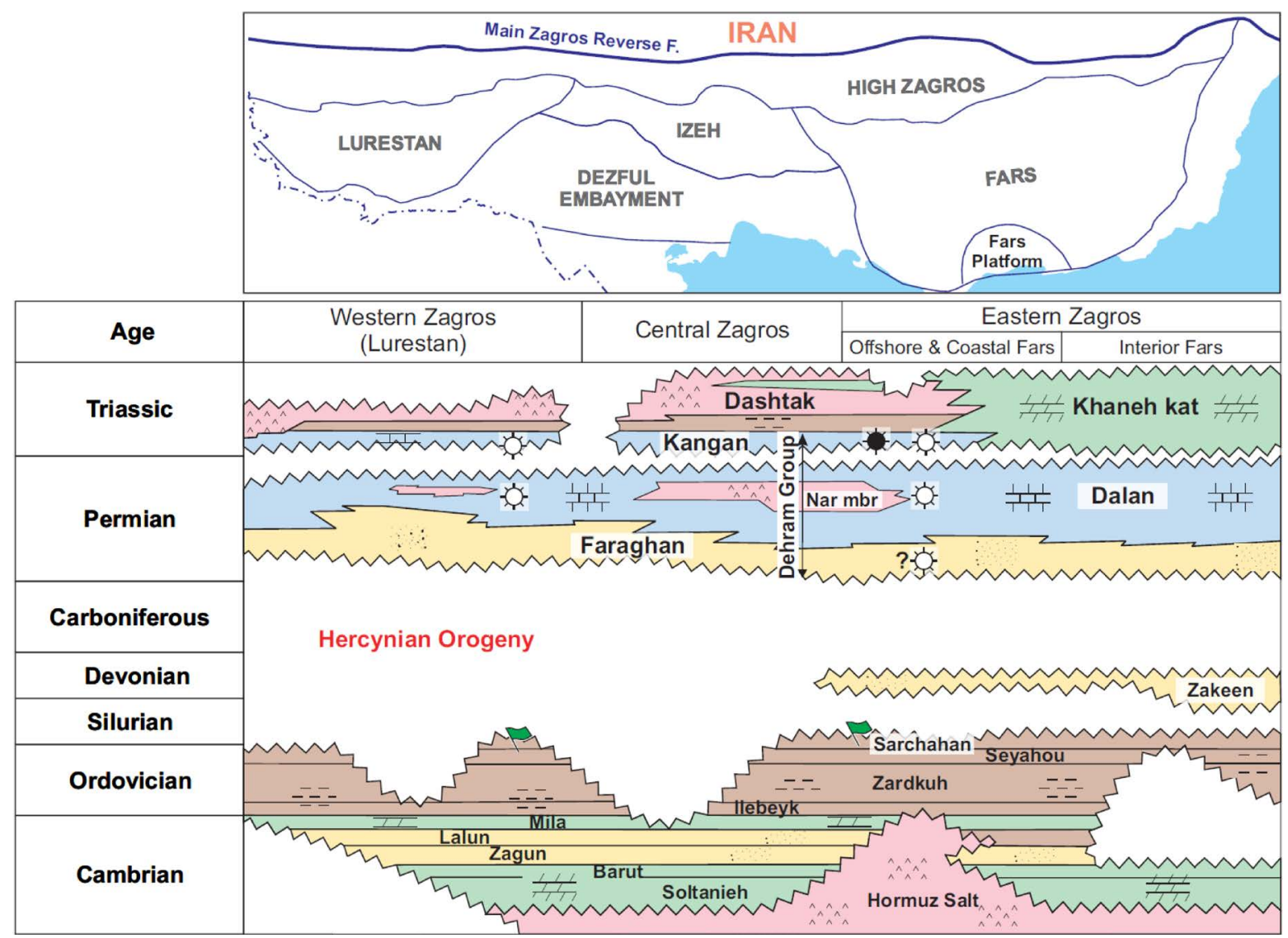

Figure 3. Stratigraphic column. Source-rocks are indicated with Green flag, Gas reservoirs with white sun mark and oil reservoirs with black sun mark (modified after Motiei, 1993 by Esrafili-Dizaji and Rahimpour-Bonab, 2013).

necessary for this. There are many types of folds in the fold and thrust belts which they have formed fold system patterns. For example, at the core zone of the ideal orogenic belt high-grade metamorphism caused to intense folding that could be affected by different types of décollements depths. The folds are usually cylindrical with horizontal hinges in the marginal parts of the fold and thrust belts and they are composed from unmetamorphosed rocks. The folds tend to be upright and open in the foreland basins and they tend to be isoclinal and inclined to recumbent in the hinterland with vergence toward the foreland. The folds may be associated with fault-ramp folds, especially toward the foreland basins and/or they tend to die out at décollements at depth [10] [11].

Description of a fold and understanding how it has developed are the main concepts for identification of the fold style. Because the Tabnak anticline is enormous sweet gas field onshore, the analysis of fold style elements is seems necessary. The stereoplots (output of Tectonics FP software) have prepared for seven parts of the Tabnak anticline, based on Twiss and Moors (1992) for description of fold. According to results, stereoplots show the location of axial plane (AP) and cylindricity (AC) and Plunge of Fold (P) (Figure 5). This part has done based on seven structural cross sections and topographic sections of the Tabnak anticline. The locations of these structural cross sections (from A-A' to G-G') is shown in Figure 4.

It is important for indication of folding mechanism, and different parts of the considered anticline have been investigated after classification attentively. We used fold style elements analysis methods (description of folds) based on [10]-[13]. We used Tectonics FP software for prepared and analyzed Stereoplots of the Tabnak anticline. In addition, we used Global Mapper Software forprepared3D SRTM of the study area and 3D Path Profile (along cross sections) based on Global Mapper Software.

Based on stereographic analysis in different parts of the study anticline (Figure 5), fold type is a semi-conical to cylindrical. The Tabnak gas field has asymmetric structure with monoclinic symmetry. Based on the obtained analysis, the geometry of the axial surface of the Tabnak anticline is plane type. Dip value of northern flank is 


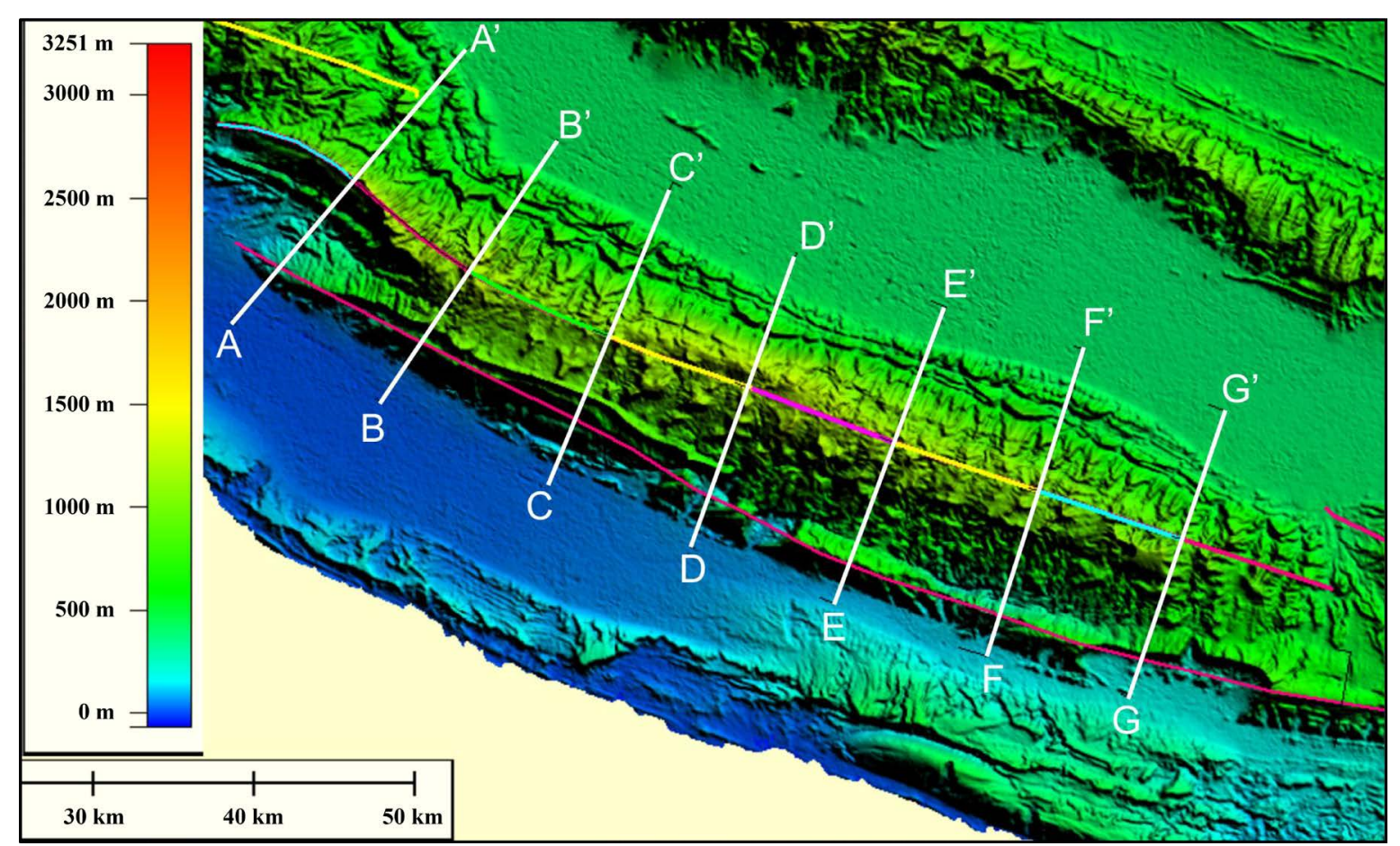

Figure 4. Location of studied structural sections on the SRTM image of the Tabnak anticline.

variable between 64 - 43 degrees and dip value of southern flank is between 75 - 61 degrees. Based on the fold style elements analysis of the Tabnak anticline, this anticline has changes in the folding style.

The fold type in A-A', C-C', D-D', E-E' parts of the study anticline is Upright sub-horizontal, in B-B' is steeply inclined sub-horizontal and in the F-F', G-G' is Upright gently plunging (Figure 6). Based on analysis of the fold style elements, the Tabnak anticlinal structure has variation in fold style. This structure has three different fold styles in different parts. The changes of fold axis, axial plane characteristics and fold classification confirmed various fold styles in different parts of the Tabnak anticline. These changes are observed specially in B-B', F-F' and G-G' sections of this anticline. It seems that these parts has been suffered more deformation in the study anticline. Also, based on Interlimb and folding angle, fold type is close type in all of parts. The close type required more accuracy, Because of close type may be has been ensigns of complication Tectonic Regime. In the study area, G-G' and F-F' section of the Tabnak gas field probable show folding style changes have been affected by Gavbandy Paleo-high.

The characteristics changes of axial plane and fold axis obtained from different parts of the anticline, represents different styles of fold in parts B-B', F-F' and G-G' be compared to other parts of the anticline. Also in F-F', G-G' parts can be seen change of fold plunge considerably compared to other parts. It seems that B-B', F-F' and G-G' parts of the Tabnak Gas field with anticlinal structure have been suffered more deformation compared to other parts. Based on the interlimb angle and folding of fold study anticline is close type in all parts. In addition, based on the Rickard Classification (1971) [13], the Tabnak anticlinal structure has three type of fold (Figure 7). This classification results have shown in Table 2. All of the study profiles of the Tabnak anticline have seen in Figure 8 .

\section{Conclusions}

Based on analysis of the fold style elements, the Tabnak anticlinal structure has variation in fold style. This structure has three different fold styles in different parts. The changes of fold axis, axial plane characteristics and fold classification confirmed several fold styles in different parts of the Tabnak anticline.

These changes are observed specially in B-B', F-F' and G-G' sections of this anticline. It seems that these parts has been suffered more deformation in the study anticline. In addition, based on Interlimb and folding angle, fold type is close type in all of parts. The close type required more accuracy, because of close type may be ensigns of complication Tectonic Regime. In the study area, G-G' and F-F' sections of the Tabnak gas field probably 
M. Badrkhani et al.

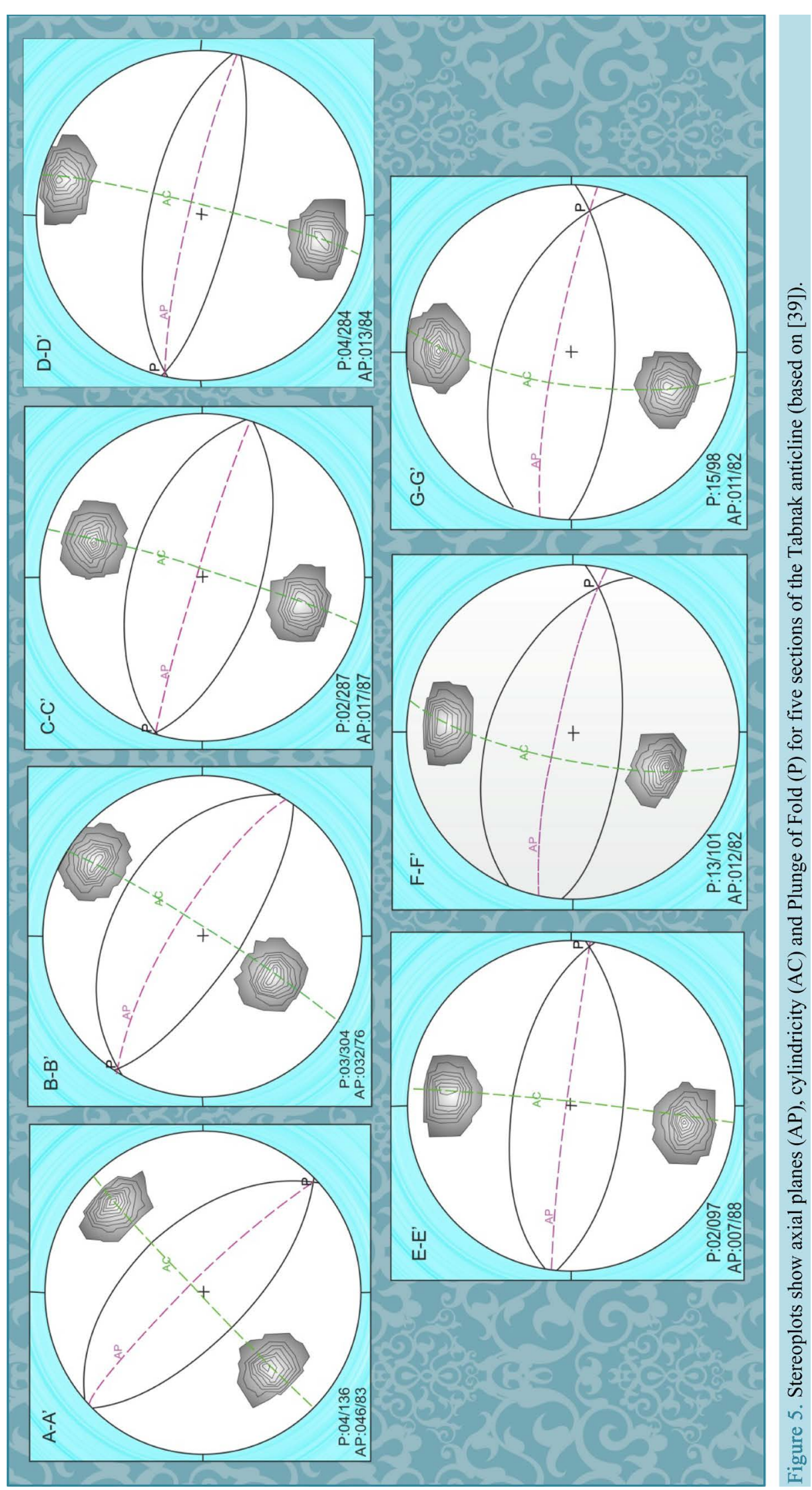


Table 2. Classification of fold based on Rickard (1971) [13] in the Tabnak anticline.

\begin{tabular}{cc}
\hline & Tabnak Anticline \\
\hline Section & Fold name \\
\hline A-A' & Upright horizontal fold \\
B-B' & horizontal foldInclined \\
C-C' & Upright horizontal fold \\
D-D' & Upright horizontal fold \\
E-E' & Upright horizontal fold \\
F-F' & Upright inclined fold \\
G-G' & Upright inclined fold \\
\hline
\end{tabular}

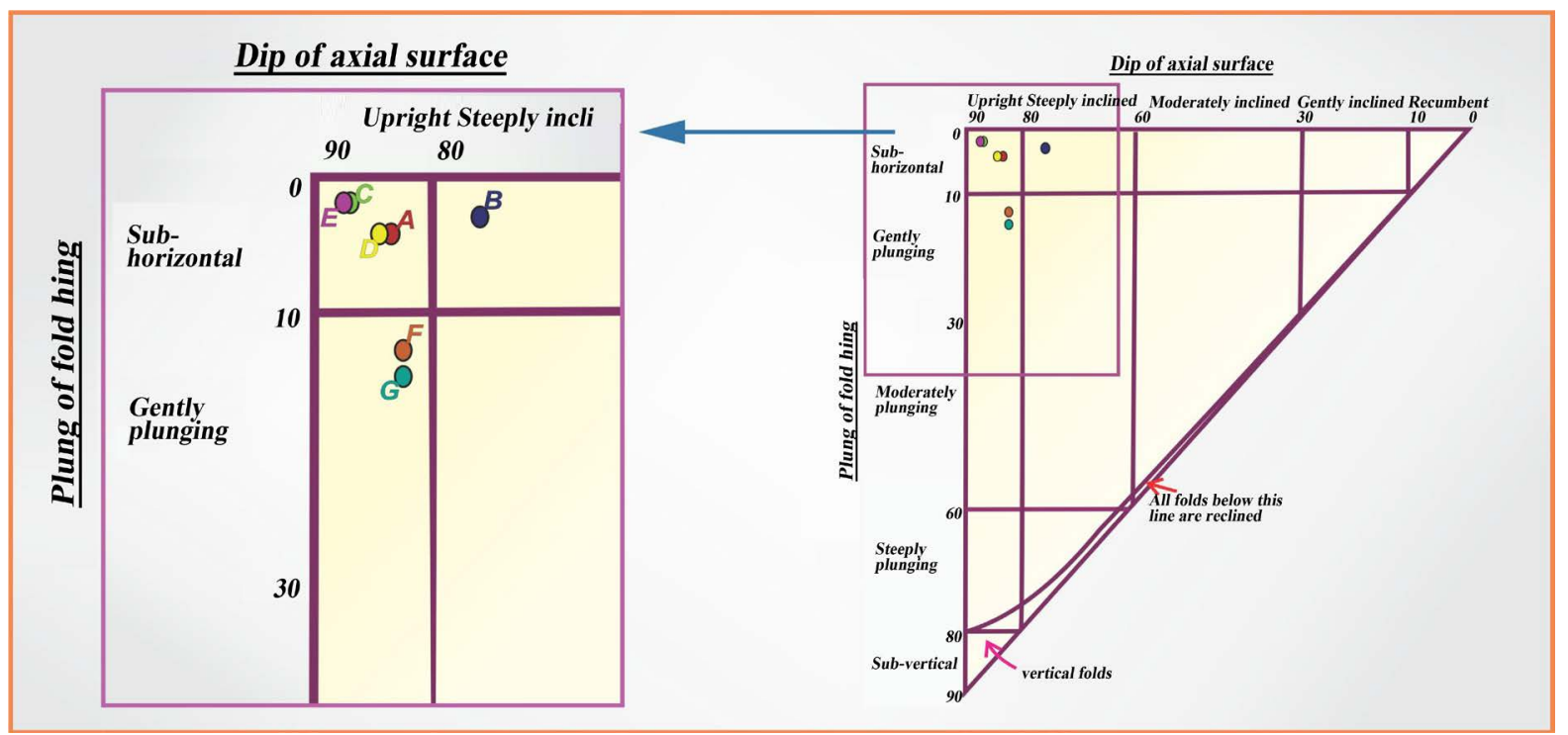

Figure 6. This figure shows the classification of fold orientation in the Tabnak anticline based on [13].

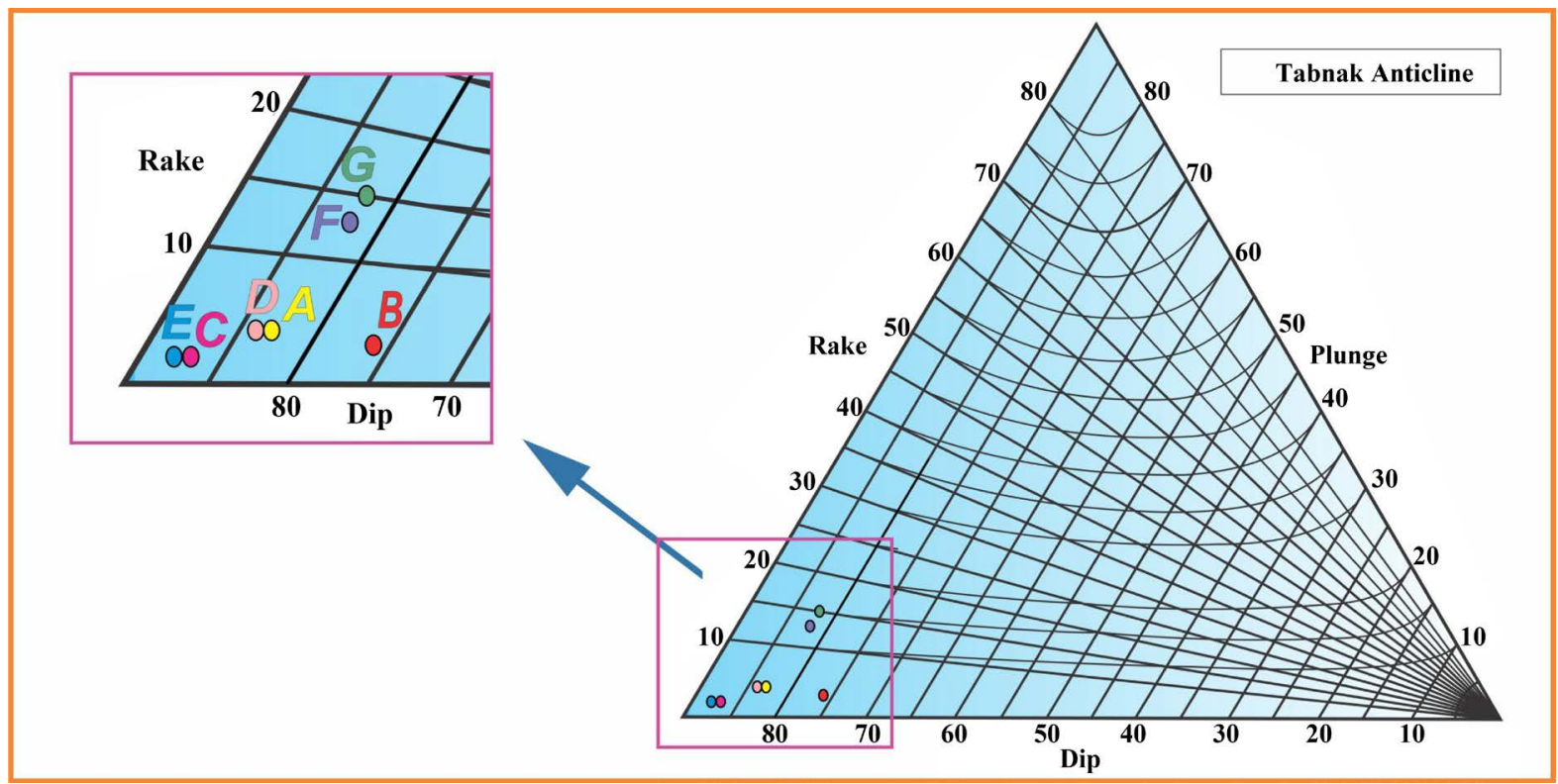

Figure 7. Triangle form diagram shows type of fold in sections of the Tabnak anticline, based on [13]. 

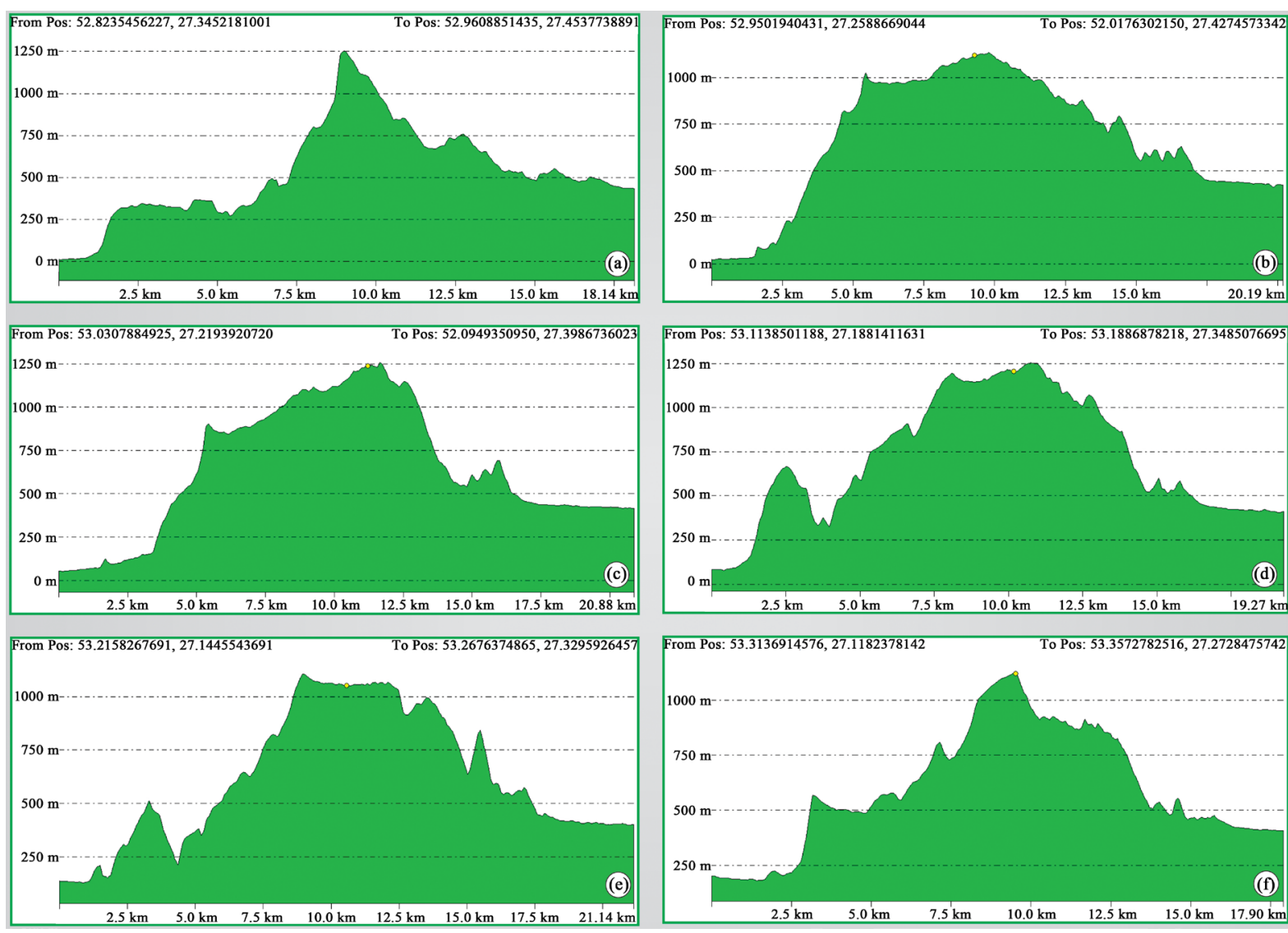

Figure 8. Topographic section or 3D profile path of the Tabnak anticline. The letters a to $\mathrm{f}$ in this figure have shown A-A' to F-F' studied profiles of the Tabnak anticlines.

show folding style changes that have been affected by Gavbandy Paleo-high.

Based on stereoplots that have been prepared for the Tabnak gas field, it can be seen that this anticlinal structure has considerable variation of folding style in some partsespecially in F-F' and G-G' parts. The dip direction of axial plane in all parts of the study anticline is towards the northeast and this case can indicate that this anticline has not been affected by specific structural elements such as basement faults or other structural elements. However, the dip value of the axial plane in B-B' part has the low dip (76 degrees) relative to the other parts. This case may be shown that one main structural element has effect on this part. The main change on the fold style elements has been caused by tectonics stress and then tectonic deformation. The characteristics changes of axial plane and fold axis obtained from different parts of the anticline represent different styles of fold in parts B-B', F-F' and G-G' compared to other parts of the anticline. Also, in F-F' and G-G' parts, considerable change of fold plunge can be seen compared to other parts. It seems that B-B', F-F' and G-G' parts of the Tabnak Gas field with anticlinal structure have been suffered more deformation compared to other parts.

According to the interlimb and folding angle of the Tabnak anticline, this fold in all of the part has close type. According to this case, the close type of fold has been required more attention from view of structural analysis, and this type of fold would be able to represent specific conditions of the deformation in the tectonics regime. In totally, it seems that this gas field anticlinal has been suffered great deformation in terms of dominant tectonic conditions. Maybe this anticlinal trap has been suffered more tectonic stresses and for this reason this hydrocarbon reservoir during the tectonic regimes has more stress tolerance and this case has effected on creation of gas hydrocarbon reserves. This is means that more tectonic stress may be caused separation of atoms syndication of hydrocarbons then gas production under these conditions in this sweet gas field. This interpretation may be indicating that tectonic effects can play a positive role for maturity of Kerogen under tectonic stress. In addition, it seems that the G-G', F-F' parts of the Tabnak gas field have been suffered more deformation than other parts influenced by the Gavbandi Paleo-high and this case causes changes on the folding style. If the Gavbandi Pa- 
leo-high activities considered under tectonic stress effects, so it can be shown that the role of tectonic stresses on hydrocarbon breaks, especially in the Permo-Triassic units of the Fars area affected by Gavbandi Paleo-High activity because of tectonic stresses creation.

\section{Acknowledgements}

The authors acknowledge the Department of geology, Islamic Azad University, Science and Research branch, Tehran, Iran for funded this project. In addition, we thank Vice-President for Research in Science and Research branch, Tehran.

\section{References}

[1] Molnar, M. (2006) Tertiary Development of the Zagros Mountains. Geol 418-Earth History.

[2] Bordenave, M.L. and Huc, A.Y. (1995) The Cretaceous Source Rock in the Zagros Foothills of Iran: An Example of a Large Size Intracratonic Basin. Revue de l'Institute Francais du Petrole, 50, 727-753.

[3] Esrafili Dizagi, B. and Rahimpour Bonab, H. (2013) A Review of Permo-Triassic Reservoir Rocks in The Zagros Area, SW Iran: Influence of The Qatar-Fars Arch. Journal of Petroleum Geology, 36, 257-279. http://dx.doi.org/10.1111/jpg.12555

[4] Kashfi, M.S. (1992) Geology of the Permian "Super-Giant” Gas Reservoirs in the Greater Persian Gulf Area. Journal of Petroleum Geology, 5, 465-480.

[5] Alsharhan, A.S. and Nairn, A.E.M. (1994) Geology and Hydrocarbon Habitat in the Arabian Basin: The Mesozoic of the State of Qatar. Geologie en Mijnbouw.

[6] Bordenave, M.L. (2008) The Origin of the Permo-Triassic Gas Accumulations in ... of the Palaeozoic Petroleum System. Journal of Petroleum Geology, 31, 3-42. http://dx.doi.org/10.1111/j.1747-5457.2008.00405.x

[7] Aleali, M., Rahimpour-Bonab, H., Moussavi-Harami, R. and Jahani, D. (2013) Environmental and Sequence Stratigraphic Implications of Anhydrite Textures: A Case from the Lower Triassic of the Central Persian Gulf. Journal of Asian Earth Sciences, 75, 110-125.

[8] Bordenave, M. and Hegre, J. (2010) Current Distribution of Oil and Gas Fields in the Zagros Fold Belt of Iran and Contiguous Offshore as the Result of the Petroleum Systems. Geological Society, London, Special Publications, 291353. http://dx.doi.org/10.1144/SP330.14

[9] Arian, M. (2013) Physiographic-Tectonic Zoning of Iran’s Sedimentary Basins. Open Journal of Geology, 3, $169-177$. http://dx.doi.org/10.4236/ojg.2013.33020

[10] Ragan, D.M. (1985) Structural Geology, an Introduction to Geometrical Techniques. 3rd Edition, John Wiley \& Sons, Inc., 210-215.

[11] Twiss, R.J. and Moores, E.M. (1992) Structural Geology. W.H. Freeman and Company, New York, 532.

[12] Ramsay, J.G. (1967) Folding and Fracturing of Rocks. McGraw-Hill, New York, 568.

[13] Rickard, M.J. (1971) A Classification Diagram for Fold Orientation. Geological Magazine, 108, 23-26. http://dx.doi.org/10.1017/S0016756800050925

[14] Falcon, N. (1974) Southern Iran: Zagros Mountains. In: Spencer, A., Ed., Mesozoic-Cenozoic Orogenic Belts, Vol. 4, Geological Society, London, Special Publications, 199-211. http://dx.doi.org/10.1144/GSL.SP.2005.004.01.11

[15] Maleki, Z., Arian, M., Solgi, A. and Ganjavian, MA. (2014) The Elements of Fold Style Analysis in the Khaftar Anticline, Zagros, Iran. Open Journal of Geology, 4, 79-92. http://dx.doi.org/10.4236/ojg.2014.43008

[16] Maleki, Z., Arian, M. and Solgi, A. (2014) Structural Style and Hydrocarbon Trap of Karbasi Anticline, in the Interior Fars Region, Zagros, Iran. Solid Earth Discussions, 6, 2143-2167. http://dx.doi.org/10.5194/sed-6-2143-2014

[17] Arian, M., Maleki, Z. and Noroozpour, H. (2011) Cenozoic Diastrophism and Deformational Events in the EastCentral Alborz. Journal of Basic and Applied Scientific Research, 1, 2394-2400.

[18] Maleki, Z. (2015) The Unique Folding Style in the Zagros Simply Folded Belt, the Kuh-e Qazi Anticline, South Iran. Open Journal of Geology, 5, No. 7.

[19] Maleki, Z. and Jahadgar, F. (2015) Folding Style of the Kuh-e Siah Anticline in the Sarvestan Area, Interior Fars, Zagros, Iran. Open Journal of Geology, 5, No. 8.

[20] Baghbanan, A., Maleki, Z. and Pourkemani, M. (2015) Structural Style in the Khalfani Anticline, Coastal Fars, Zagros Fold-Thrust Belt. Open Journal of Geology, 5, No. 9.

[21] Rafieh, Z., Maleki, Z., Zare, M. and Ghaitanchi, M. (2011) Seismic Zonation and Hazard Assessment in Lorestan 
Province Region. Journal of Sciences, 61, 51 p. (In Persian)

[22] Vaseghi, H., Maleki, Z. and Arian, M. (2016) Structural Style in the Zagros Fold-Thrust Belt: The Gavbast Anticline, Coastal Fars. Open Journal of Geology, 6, No. 2.

[23] Abdolizadeh, S., Maleki, Z. and Arian, M. (2016) Earthquake Hazard Zonation and Seismotectonics of the Bandar Abbas Area, Zagros, Iran. Open Journal of Geology, 6, No. 3.

[24] Hajnorouzi, N., Pourkemani, M. and Maleki, Z. (2016) Hydrocarbon Trap and Folding Style of the Pishvar Anticline, Sub-Coastal Fars, Zagros. Open Journal of Geology, 6, No. 6.

[25] Maleki, Z., Arian, M., Solgi, A. and Ganjavian, M.A. (2014) The Elements of Fold Style Analysis in the Khaftar Anticline, Zagros, Iran. Open Journal of Geology, 4, No. 3.

[26] Maleki, Z., Arian, M., Solgi, A. and Ganjavian, M.A. (2013) Sediment Deformations on Strike Slip Fault Blocks and Analogue Modeling: A Case Study of Nezamabad Fault, interior Fars, Zagros. Journal of Sciences, 89, 39-51. (In Persian)

[27] Maleki, Z., Arian, M. and Solgi, A. (2015) Folding Pattern in the Fars Province, Zagros Folded Belt: Case Study on the Karbasi and Khaftar Anticlines, Interior Fars, Iran. Solid Earth Discussions, 7, 2347-2379. http://dx.doi.org/10.5194/sed-7-2347-2015

[28] Maleki, Z., Arian, M., Solgi, A. and Ganjavian, M.A. (2015) Elements of Fold Style Analysis in the Karbasi Anticline,Interior Fars Region, Zagros. Geosciences, 24, 293-302.

[29] Berberian, M. (1995) Master Blind Thrust Faults Hidden under the Zagros Folds: Active Basement Tectonics and Surface Morphotectonics. Tectonophysics Journal, 241, 193-224.

[30] Stockline, J. (1968) Structural History and Tectonics of Iran: A Review. AAPG Bulletin, 52, 1129-1258. http://dx.doi.org/10.1016/0040-1951(94)00185-C

[31] Motiei, H. (1993) Stratigraphy of Zagros. Treatise on the Geology of Iran. Ministry of Mines and Metals, Geological Survey of Iran, Tehran.

[32] Tabatabaei, H. (2001) Geological Map of the Zagros, Iran. National Iranian Oil Company.

\section{Submit or recommend next manuscript to SCIRP and we will provide best service for you:}

Accepting pre-submission inquiries through Email, Facebook, LinkedIn, Twitter, etc.

A wide selection of journals (inclusive of 9 subjects, more than 200 journals)

Providing 24-hour high-quality service

User-friendly online submission system

Fair and swift peer-review system

Efficient typesetting and proofreading procedure

Display of the result of downloads and visits, as well as the number of cited articles

Maximum dissemination of your research work

Submit your manuscript at: http://papersubmission.scirp.org/ 